\title{
Activities of a Scientific Reference Library
}

J. Christian Bay is librarian of the John Crerar Library, Chicago, whose reference activities he describes in this article.

$\mathrm{T}$ HE CRERAR opened its doors in 1895 as a reference library devoted to the collection and presentation of scientific and technical research material. The organization, from the beginning, was circumspect, complete, and supported by a wide and liberal view of the literature involved. We never dealt with abstract masses of literature, or units, as some say. In about forty years we succeeded in securing the fundamental periodicals, serials, and classics within our prescribed field. It was a fine effort, the result of a composite selective judgment of many experienced and critical minds. The present status is that we now are more frequently surprised at what we possess than at what we lack. In time about a dozen personal collections of well-known scholars were acquired, covering various broad fields within the general subject of economics, physical and natural science, and technology. We had the good fortune of buying complete sets of most of the important periodicals and serials before they grew voluminously or financially unwieldy. Of the classics in our province, the fundamental and monumental works, we secured our liberal share long before these works became subject to systematic financial exploitation. We should be unlikely to contribute very much to a storage house of secondary material, if Chicago possessed one.

Some of you will know that the Crerar always emphasized historical actualities of the present and of the past. Our historical apparatus in science and technology is said to be of a high order. As time passes, more and more of our research material takes on the historical aspect and beams with rarity and craves special protection and care, even though we do not wish to make too many formal restrictions in the use of our holdings. Most of this select or cornerstone acquisition now increasingly evades even a diligent search.

This is the general situation of the Crerar. We always have benefited by independent and very liberal-minded directors, under whose authority the two successive librarians have pursued definite lines of historical continuity. Certain policies, such as the measured acquisition of current material for general study and a liberal interlibrary loan policy, or the generous participation in the development of bibliographical centers in the Westsuch policies have had our hearty support and probably will lead to other movements in which we might be privileged to participate.

Our old friend, Mr. Hamlin Garland, when he reached the age of sixty, used to 
say that now he considered himself free to tell his reminiscences. When you draw close to the age of seventy, however, you are permitted not only to reminisce, but to prophesy. When we are young, we make history; when we are old, we prophesy.

\section{Thirty-five Years Experience}

With a background of over thirty-five years of experience at the Crerar, I prophesy that a knowledge of books, both as regards their form and their contents, will increasingly be indicated for the responsible personnel in such libraries as ours. Probably the most frequent complaint among trained patrons is that libraries fail to comprehend their language and miss the correct appreciation of their metaphors and so their problems. Such an understanding, of course, is a matter of cumulative experience. We all know that the relative ignorance of beginners in regard to specific subjects and scientific facts or methods usually is relieved by actual library service after they leave the library schools, and I also am well aware that the library schools cannot possibly make their students adequately familiar with fifty or one hundred thousand individual books by the time they are obliged to graduate them. Much less can our schools convey the requisite knowledge of the ideologies which such books represent. In general literature, the humanities, and the historical sciences, book-knowledge comes more easily than in the inductive sciences and their applications. I have great hopes for the modern development of semantics as applied to library life. But above all I foresee that a time will come when at least the fundamental and permanently valuable books in our own literature will be understood and analyzed and evaluated much more than they are now. This probably may be accomplished by a system of post-graduate volunteer service in our larger libraries, and by a systematic effort on the part of such libraries to coach ambitious persons in this field of essential knowledge.

Every person with any ambition at all grieves for some lost opportunity. My own lost opportunity is that I never have been permitted to teach library science as it is understood by the Crerar Library. In all my life I have had only one student. She was a volunteer. She came to me one hour every day, and in the course of about half a year I inspected and analyzed with her daily some classical or very important book in some branch of science and technology, calling her attention to the important features of the book, its historical position in the development of its subject and its significance generally for the purpose of professional study. She left me with a notebook containing about a thousand entries, each devoted to a critical analysis of some book that had been explained to her. I am afraid that I shall never have such an opportunity again, but it seemed greatly worth while to me while it lasted. There are genealogies of persons dead and gone, but there also are genealogies of families of books, their purposes, their rank.

\section{Tyranny of Cataloging}

I prophesy also, with all due care to my reputation, that the terrible ordeal of cataloging will be somehow alleviated before very long. The last number of the Crerar Library Quarterly shows that we are fully aware of the tyranny of cataloging to which all of us have been exposed of necessity, while our large libraries were being cataloged fully and completely during the past fifty years. In many instances 
the furor of cataloging has taken the wind out of the sails of many other functions, and therefore, while persisting in doing full justice to the books of continuous use and value, we have developed a scheme of modified cataloging for material which does not promise to be of lasting or permanent value. This does not mean what commonly has been termed "simplified cataloging." Cataloging cannot be simplified without a loss of valuable information, but a selective and suitable treatment of secondary sources of information by treating them according to their lesser merits, shortening the process, and yet doing reasonable justice to everybody concerned, strikes me as a useful movement, and also an economic one.

\section{Explain Intricacies of Catalog}

The catalogers need not feel that any attempt at a modification in the treatment of certain groups of books will injure our professional standing or our reasonable means of gaining a livelihood, because if any time should be saved from the ardent work of giving attention to cataloging details, that time may be used profitably in our reference rooms, in explaining the intricacies of our catalogs to the unwary and stumbling public. We have built up enormous catalogs, parts of which are almost incomprehensible to the average reader except by expert aid. It is possible that a chronological division of these enormous catalogs is approaching! It also is possible that the further subdivision of large and cumbersome subject groups is necessary and desirable. Our classifiers have experimented with our subject cata$\log$ in regard to these conditions, and further work is planned, but that also is within the province of prophecy.

I foresee that some time the use of libraries throughout our country will be systematized as it should be; that our small libraries will be standardized and then supplemented or supported by regional libraries of a higher order; that the regional libraries in turn will permit themselves to develop along systematic lines and not in a haphazard way, and finally, that we shall have regional centers of research connecting upward with our vast national collections and downward through the regional libraries and their ramifications in the smaller communities. Other countries, the governments of which are based on equal educational and social opportunity, have found it advantageous to systematize the library facilities in this way. If something of this kind were in force nowadays, the Crerar Library would not find it necessary to extend its interlibrary loan service to about four hundred institutions scattered all over this continent, including Canada.

I can assure you that some form of intelligent standardization also will prevent the accumulation in many smaller and even larger libraries of dead and decaying timber and help in the acquisition of young and live books where such are demanded.

Jointly we may prophesy, I think, that interlibrary loans will be granted free posting privileges by our government. . It is a relatively small but enormously important privilege that we have a right to ask and expect. Such a privilege of course would imply that the system of library-to-library loans of research material be rigidly followed.

\section{Analysis of Reference Work}

This function of ours has been studied very successfully in connection with a thorough analysis of our formal reference 
activities by Mr. Thomas Spencer Harding, of the Graduate Library School, University of Chicago. Mr. Harding's work, which was undertaken at my suggestion, brings out the Crerar's relations to the various geographical and educational groups of Chicago, the service given in reference work and in research (a valuable distinction). Mr. Harding also presented a most exhaustive analysis of our interloan status. It shows that we borrow 2 per cent of the amount which we lend. It shows also that libraries, corporations, hospitals, and laboratories very frequently go far afield to present their requests to us. It shows conclusively that the union catalog in the Library of Congress, if consulted before a request were made, would help distribute the responsibility. This procedure would be very desirable wherever a short delay does not matter. Exceptions would be such loans as affect urgently needed information or research material on the use of which human welfare depends.

At the Crerar, we always assume that interlibrary loan calls are urgent, and we act upon them without delay. We hopeand this is my last prophecy-that very soon we all may agree upon a definite form of request, uniform in wording, uniform in size. A standard-size loan request card would be quite a desirable invention, as it would facilitate our filing and our classification of the requests which come to us.

In 1906 we granted forty-six interlibrary loans, in 1939 we had the pleasure of granting nearly three thousand. It is good work. It is worth while sharing in it. Some day we all shall get together and systematize its practice.

\section{Scholarship for Illinois Library School}

The Katharine L. Sharp scholarship for graduate (i.e., second year) study in library science at the University of Illinois Library School will be awarded again this year. The stipend available is $\$ 300-\$ 600$. The holder of the scholarship is exempt from the payment of tuition ( $\$ 80$ for resident students; $\$ 160$ for non-resident).

Miss Sharp, for whom the scholarship is named, organized the library school at Armour Institute, Chicago, and conducted it there for four years; she was then, in 1897, made librarian of the University of Illinois, and the library school was transferred to Illinois, where she remained in charge as director until 1907 .

The scholarship has been endowed by the University of Illinois Library School Association. Usually the award is made in April. Application blanks may be secured from the assistant director, University of Illinois Library School, Urbana. 